\title{
PENGARUH PENGGUNAAN MEDIA PEMBELAJARAN DAN PENGUASAAN KOSAKATA TERHADAP KETERAMPILAN MENULIS CERPEN
}

\author{
Lutfi \\ Pendidikan Guru Sekolah Dasar, Fakultas Ilmu Pendidikan, \\ Universitas Muhammadiyah Jakarta, \\ Jalan K.H. Ahmad Dahlan, Cireunde, Ciputat Timur, Tangerang Selatan, Banten \\ lutfi@umj.ac.id
}

\begin{abstract}
ABSTRAK
Media pembelajaran adalah salah satu faktor yang menentukan kualitas pembelajaran di kelas. Guru harus, memenuhi kriteria pemilihan media yang akan digunakan. Perlu diperhatikan kriteria yang rasional, ilmiah, ekonomis, dan praktis'Sebaik apapun media yang dipilih, bila tidak digunakan degan secara maksimal tentunya tidak bermanfaat. Hal ini yang menjadi pembahasannya adalah media pembelajaran seperti apa yang dapat diterapkan pada pembelajaran, agar membantu siswa memudahkan pemahaman apa diberikan dan membantu peserta didik untuk mempermuda mengembangkan proses materi ajar. Menurut Donald P.Edy dalam Sudarman Danim mengemukakan kegunaan media teknologi pada pendidikan yaitu; meningkatkan kualitas pendidikan, memberikan kemungkinan kegiatan bersifat individual, memberi dasar lebih dinamis terhadap pendidikan, pembelajaran yang lebih berkualitas, membuat belajar secara seketika dan pennyajian pendidikan lebih luas Mengetahuai antara penggunaan media pembelajaran dan penggunaan kosakata terhadap menulis cerpen. Sempel pada penelitian ini melibatkan 60 siswa. Dibagi menjadi dua kelas, satu kelompok kelas eksperimen dan dua kelompok kelas kontrol. Terdapat dua jenis intrumen yang digunakan dalam peneitian ini yakni satu intrumen teks penguasaan kosakata. Kedua intrumen tersebut dilakukan kalibrasi intrumen untuk mengetahui kualitas (validitas dan reabilitas) intrumen. Hasil penelitian menunjukan pengaruh yang signifikan penggunaan media pembelajaran pemutaran filem dokumenter terhadap penulisan cerpen.
\end{abstract}

Kata kunci: Media, Kosakata, Cerpen

\section{PENDAHULUAN}

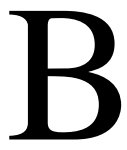
elajar mengajar adalah kegiatan prosedural yang sesuai dengan kurikulum yang dirancang oleh lembaga pendidikan, untuk mencapai tujuan pendidikan pada hakikatnya. Pendidikan pada dasarnya mengarahkan siswa pada perubahan tingkah laku baik intelektual, moral maupun sosial agar hidup mandiri sebagai individu dan makhluk sosial. Tujuan tersebut berinteraksi pada 
Lutfi: Pengaruh Penggunaan Media Pembelajaran dan Penguasaan Kosakata terhadap Keterampilan Menulis Cerpen.

Website : https://jurnal.umj.ac.id/index.php/penaliterasiEmail : penaliterasi@umj.ac.id

lingkungan belajar yang diatur oleh pengajar melalui proses pengajaran.

Lingkungan belajar yang direkayasa oleh pengajar untuk mencapai tujuan pengajarkan, metodologi pengajaran dan penilaiannya. Hal tersebut bisa dengan unsur-unsur pengajaran. Rumusan Tujuan pengajaran adalah kemampuan yang diharapkan para siswa setelah ia menempuh berbagai pengalaman belajarnya (pasca belajar).

Bahan pengajaran yaitu seperangkat keilmuan yang terdiri atas generalisasi konsep, dan prinsip keilmuan bersumber dari kurikulum yang menunjukkan tercapainya tujuan belajar. Metodologi pengajaran adalah metode, pendekatan, dan teknik digunakan pengajar untuk berbuat interaksinya pada siswa agar materi sampai ke siswa, sehingga mencapai tujuan pengajaran bersama.

Ada dua aspek yang paling menonjol dalam metodologi pengajaran yaitu media dan metode pengajaran sebagai bahan ajar. Dalam pengajaran ada yang disebut penilaian. Untuk mengukur atau menentukan taraf tercapai tidaknya pembelajaran. Pada uraian tersebut disimpulkan bahawa kedudukan media pengajar sebagai alat bantu pengajarana ada dalam komponen metodologi, sebagai salah satu lingkungan belajar yang diatur oleh guru.

Indriana (2011) Media pembelajaran adalah salah satu faktor yang menentukan kualitas pembelajaran di kelas. Guru harus, memenuhi kriteria pemilihan media yang akan digunakan. Perlu diperhatikan kriteria yang rasional, ilmiah, ekonomis, dan praktis
Sebaik apapun media yang dipilih, bila tidak digunakan degan secara maksimal tentunya tidak bermanfaat. Hal ini yang menjadi pembahasannya adalah media pembelajaran seperti apa yang dapat diterapkan pada pembelajaran, agar membantu siswa memudahkan pemahaman apa diberikan dan membantu peserta didik untuk mempermuda mengembangkan proses materi ajar. Menurut Donald P.Edy dalam Sudarman Danim (2010) mengemukakan kegunaan media teknologi pada pendidikan yaitu; meningkatkan kualitas pendidikan, memberikan kemungkinan kegiatan bersifat individual, memberi dasar lebih dinamis terhadap pendidikan, pembelajaran yang lebih berkualitas, membuat belajar secara seketika dan pennyajian pendidikan lebih luas.

Arsyad, (2010) Guru agar memilih media pembelajarn yang sesuai dengan materi pembelajaran adalah suatu alat bantu yang turut berhubungan iklim, kondisi, dan lingkungan belajar yang ditata dengan menciptakan oleh guru. Maka dari itu dituntut ketepatan dan kreatifitas guru untuk memilih serta mengembangkan media yang efektif dipakia untuk membantu dan memotivasi siswa dalam mengembangkan materi yang akan disampaikan kepada siswa misalnya mengembangkan kemampuan belajar menulis cerpen, agar dapat menulis dengan baik. Sudjana, (2013) Tetapi di lapangan banyak guru yang belum tepat dalam memilih media pembelajaran yang mengakibatkan kurangnya pemahaman materi ajar yang diberikan guru pada siswa.

Di samping itu kemampuan kosakata sangat berhubungan dengan menulis cerpen. Gorys Keraf (2000) Kosakata 
Lutfi: Pengaruh Penggunaan Media Pembelajaran dan Penguasaan Kosakata terhadap Keterampilan Menulis Cerpen.

Website : https://jurnal.umj.ac.id/index.php/penaliterasiEmail : penaliterasi@umj.ac.id

adalah salah satu dari komponen bahasa. Tarigan (2008) Sebagai bagian dari komponen berbahasa, kata-kata yang di gunakan dalam komunikasi baik lisan serta secara tertulis diperlukan pemilihan kata secara tepat. Saat menulis, penguasaan kosakata diperlukan untuk menyampaikan gagasannya ke dalam tulisan.

Soejito (2002) Pemahaman terhadap aspek kosa kata pada dasarnya memberikan pengaruh terhadap kuantitas penggunaan bahasa seseorang. Artinya, penggunaan bahasa yang baik menjadi cermin penggunaan kosakata yang memadai namun sebaliknya penggunaan kosakata yang kurang baik biasanya terjadi akibat penguasaan kosakata yang kurang baik pula sebagai konsekuensi penggunaan bahasa dan penguasaan kosakata yang kurang baik pula maka proses komunikasi yang dilakukan menjadi kurang optimal. Pada unsur bahasa serta unsur isi haruslah terjalin sedemikian rupa serta menghasilkan tulisan yang runtut dan efektif. Wirdarita dalam Suryadi (2018) Bahasa yang baik ialah Bahasa yang memakai ragam bahasa secara tepat sesuai situasi dan kondisi pemakainya, sedangkan Bahasa yang benar ialah yang mengikuti kaidah yang baku mencakup ejaan, tanda baca, kosakata serta tata Bahasa.

Namun kenyataannya dilapagan terdapat siswa di MTs Muhammadiyah 1 Ciputat kelas VII masih banyak dari siswa yang belum mahir dalam mengolah kosakata, baik secara lisan maupun secara tulisan karena siswa kurang mampu menguasai kosakata yang banyak. Dengan demikian, siswa kesulitan mengenal arti kata tertentu, rentan keliru dalam memaknai suatu hal yang ingin disampaikan. Hal demikian tentu mengakibatkan siswa sulit memahami apa ditulisnya atau apa yang digunakan ketika ia berbicara atau pun menulis tugas yang diberikan oleh guru di sekolah. Sama halnya dengan penelitian yang di lakukan oleh Suryadi dan milawasih tentang pengukuran kosakata responden yang menyatakan semakin banyak kosakata yang dikuasai oleh reponden maka semakin baik penulisanya juga dibandingkan mahasiswa yang tidak banyak menguasai kosakata. Apalagi tidak menggunakan pendukung yaitu media pembelajaran bahasa seperti pemutaran filem dan lain sebagainya.

Keterampilan berbahasa siswa akan lebih baik apabila siswa itu banyak menguasai kosakata begitu pula sebaliknya. Siswa dikatakan mempunyai kosakata yang banyak apabila dapat menuliskan atau menguasai makna kata-kata yang ditulisnya. Melihat adanya pengaruh antara penguasaan kosakata terhadap menulis cerpen, hal yang diperhatikan adalah bagaimana cara siswa mengembangkan ide atau gagasan yang dimiliki dengan melalui penggunaan kosakata yang tepat. Pada relevansinya siswa kurang mampu menggunkan kosakata dengan baik sehingga sering terjadi kesalahan pengucapan dan penulisan. Kesalahan tersebut justru menjadikan tulisan cerpen yang seharusnya menceritakan pengalaman sendiri, justru membingungkan pembaca.

Berdasarkan paparan di atas bahwa diduga adanya pengaruh antara kemampuan menulis cerpen terhadap variabel-variabel yang lain seperti penggunaan media pembelajaran dan penguasaan kosakata, maka penulis tertarik untuk mengaji "Penggunaan Media Pembelajaran dan Penguasaan Kosakata terhadap Kemempuan Menulis Cerpen" (studi pengaruh pada siswa kelas VII MTs 
Lutfi: Pengaruh Penggunaan Media Pembelajaran dan Penguasaan Kosakata terhadap Keterampilan Menulis Cerpen.

Website : https://jurnal.umj.ac.id/index.php/penaliterasiEmail : penaliterasi@umj.ac.id

Muhammadiyah 1 Ciputat, Tangerang

Selatan, Banten).

\section{METODE PENELITIAN}

$\mathrm{P}$ enelitian ini menggunakan Syamsuddin. Vismaia S. Damaianti. (2011) quasi eksperiment dan desain penelitian Posttest Only Control Design. Nurgiantoro, Burhan. (2007) Pada pelaksanaannya, penelitian memerlukan dua kelas, kelas pertama yaitu eksperimen atau menggunakan pendekatan Bahasa Indonesia realistis, sedangkan kelas kedua control atau kelas menggunkan konvension. Sama halnya yang dijelaskan oleh priyono (2008:135) penelitian ini dapat dilakukan di dalam alam terbuka dan juga di ruang tertutup.

Dalam penelitian eksperimen, kondisi ruang ada dimanipulasi oleh peneliti sesuai dengan kebutuhan peneliti. Dalam kondisi yang telah dimanipulas ini. biasan-v-a dibuat dua kelompok, yaitu kelompok kontrol dan kelompok pembanding. Kepada kelompok kontrol akan diberikan treatment atau stimulus tertentu sesuai dengan tujuan penelitian. Hasil dari reaksi kedua kelompok itu yang akan diperbandingkan.

\section{HASIL DAN PEMBAHASAN}

Denelitian tentang media pengajaran dan
penguasaan kosakata terhadap pembuatan cerpen menunjukan hasil data yang diperoleh skor siswa pada umumnya menulis cerpen yang diajar dengan media pngajaran melalui pemutaran filem documenter sebesar 59.9

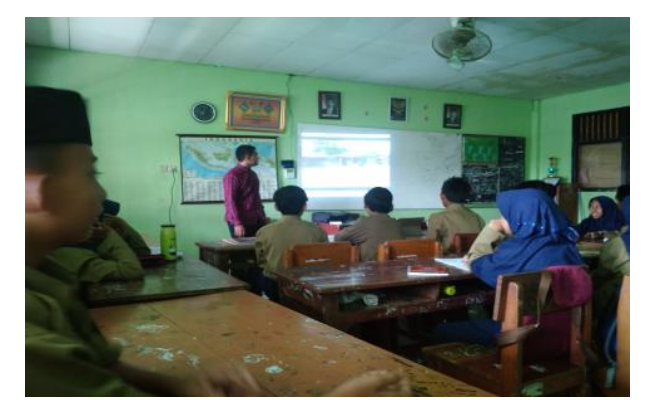

Gambar kelas yang menggunakan media pembelajaran pemutaran filem documenter

sedangkan nilai siswa menulis cerpen yang diajar dengan media teks cerpen sebesar 37 berdasarkan kedua skor rata-rata tersebut, terlihat adanya peredaan kemampuan menulis cerpen siswa.

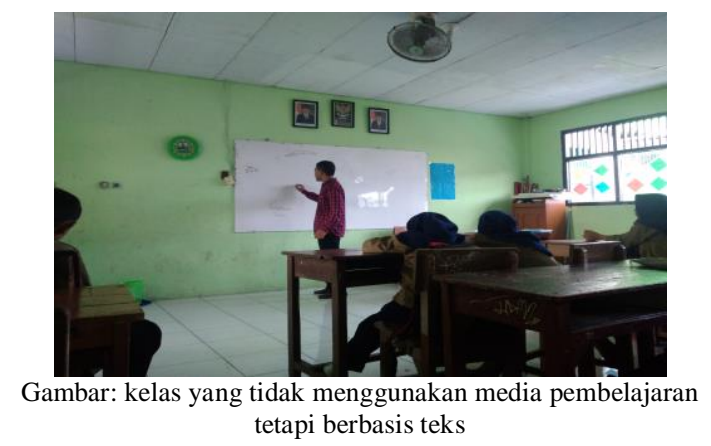

Apakah dibandingkan denagn kedua skor tersebut, skor rata-rata kemampuan menulis cerpen yang diajar dengan media pembeljaran menggunkan teks cerpen. Dapat dilihat apakah perbedaan tersebut signifikan, dilakukan pengujian signifikan, dengan uji hipotesis (uji f dan uji t).

Setelah dilakukan perbandingan menggunakan pengajuan hipitesis (uji f dan uji t) melalui program SPSS versi 21 ternyata diperoleh nilai sig= $0.00<0.05$. Memiliki makna yaitu penggunaan media pembelajaran memiliki pengaruh terhadap kemampuan menulis cerpen. Sementara $\mathrm{F}_{\text {hitung }}=33.104>\mathrm{F}_{\text {tabel }}=4.02$ Ini memiliki 
Lutfi: Pengaruh Penggunaan Media Pembelajaran dan Penguasaan Kosakata terhadap Keterampilan Menulis Cerpen.

Website : https://jurnal.umj.ac.id/index.php/penaliterasiEmail : penaliterasi@umj.ac.id

makna bahwa media memiliki pengaruh terhadap kemampuan menulis cerpen.

Hasil ini memberikan makna bahwa terdapat pengaruh yang signifikan antara kemampuan menulis cerpen yang menggunakan media pemutaran filem dokumnter dan media pembelajaran konvensional. Kemampuan menulis cerpen oleh peserta didik diajar dengan media pembelajaran pemutaran filem documenter meningkat lebih baik terhadap peserta didik yang belajar dengan media teks cepen.

Dari keempat keterampilan berbahasa dalam bahasa Indonesia menulis merupakan keterampilan cukup suit. Menulis yaitu kegiatan seseorang dapat mengekpresikan, mengutarakan, atas menyampaikan pemikiran, gagasan dan keadaan diri kepada kelompok orang atau indovidu melalui tulisan.

\section{KESIMPULAN}

B erdasarkan analisis dan pengajuan hipotesis dengan hasil penelitian mengeni korelasi penggnaan media pembelajaran serta penguasaan kosakata terhadap kemampuan menulis cerpen, diperoleh simpulan diantaranya adalah:

Ada pengaruh signifikan antarpenguasaa kosakata terhadap kemampuan menulis cerpen peserta didik kelas VII MTs Muhammadiyah 01 Ciputat yang menggunakan media pembelajaran pemutaran filem dokumenter. Terbukti dengan nilai Signifikansi $0.000<0.05$ dan nilai $\mathrm{F}_{\text {Hitung: }} 33.104$ di bandingkan kelas yang menggunakan media teks cerpen.

Terdapat hubungan interaksi yang signifikan antara penggunaan media pengajaran dan penguasaan kosakata dengan menulis cerpen pada kelas VII MTs
Muhammadiyah 01 Ciputat Tangerang Selatan Banten. Hasil pengujian diperoleh nilai sig $=33.104$ dan $\mathrm{F}_{\text {Hitung }}=33.104>$ $\mathrm{F}_{\text {Tabel }}=4.02$

\section{UCAPAN TERIMA KASIH}

$\mathbf{U}$ capan terima kasih ditujukan kepada seluruh jajaran fakultas ilmu pendidikan universitas muhammadiyah Jakarta yaitu Dekan, Wakil Dekan I, II, III yang sudah membantu menerbitkan artikel yang peneliti buat. Tidak lupa juga kepada Dosen prodi pendidikan bahasa dan sastra Indonesia, fakutas ilmu pendidikan universitas muhamadiyah jakarta, khususnya kaprodi dan pengelola jurnal pena literasi yang sudah mendukung dan memotivasi untuk terbitnya jurnal ini. Semoga Allah SWT membalas semua kebaikan yang sudah diberikan kepada penulis.

\section{REFERENSI}

Arsyad, Azhar. 2014 Media pebelajaran. Jakarta: Rajawali Perss

Danim, Sudarwan. 2010. Media KomunikasiPendidikan.Jakarta.Bumi Aksara.

Gorys Keraf. 2000. Diksi dan gaya bahasa (Jakarta: Gramedia Pustaka Utama).
Henry Guntur Tarigan 2008.Menulis Sebagai Suatu Keterampila Berbahasa.Bandung:Angkasa.

Indriana, Dina. 2011. Ragam Alat Bantu Media Pembelajaran. Yogyakarta: Diva Press. 
Lutfi: Pengaruh Penggunaan Media Pembelajaran dan Penguasaan Kosakata terhadap Keterampilan Menulis Cerpen.

Website : https://jurnal.umj.ac.id/index.php/penaliterasiEmail : penaliterasi@umj.ac.id

Nurgiantoro, Burhan. 2007. Teori Pengkajian Fiksi. Yogyakarta: Gajah Mada University Press

Soejito. 2002. Kosakata Bahasa Indonesia (Jakarta: Gramedia Pustaka Utama)

Sudjana, Nana. Ahmad Rivai. 2013. Media Pengajaran. Bandung: Sinar Baru Algensindo.

Suryadi, Edi. F.A. Milawasri. 2018. Hubungan Penguasaan Kosakata dengan Kemapuan Menulis Cerpen Mahasiswa FKIP Universitas Tridinanti, Program Studi Pendidikan Bahasa dan Sastra Indonesia. Palembang. Jurnal Bindo Sastra 2 (2) (2018);232-239.

Priyono. 2008. Metode Penelitian Kuantitatif. Sidoarjo. Zifatama Publishing.

Syamsuddin. Vismaia S. Damaianti. 2011. Metode Penelitin Pendidikan Bahasa. Bandung: PT. Remaja Rosda Karya. 